\title{
DISCURSO DEL SR. JAIME FRANCO UGARTE, PRESIDENTE DE LA I. CORTE DE APELACIONES DE LA SERENA, EN CEREMONIA DE HONOR AL SESQUINCENTENARIO DE LA I. CORTE DE APELACIONES DE LA SERENA. 19 DE AGOSTO DE 1999.
}

Señor Rector de la Universidad Católica del Norte don Juan Music Tomicic

En mi calidad de Presidente de la I. Corte de Apelaciones de La Serena quiero testimoniar mi agradecimiento frente a este homenaje que se rinde por la Escuela de Derecho de la Universidad Católica del Norte a nuestro tribunal de alzada, con ocasión de cumplirse 150 años desde la fecha en que entró en funciones el 26 de agosto de 1849 .

Muchos años han transcurrido y muchos distinguidos magistrados han ocupado los estrados de nuestra Corte de Apelaciones desde aquél día en que luego de un solemne Te Deum y con la concurrencia del Sr. Intendente y Comandante de Armas, don Juan Melgarejo, ella se inauguró concurriendo a tal acto su Presidente, o Regente como se le llamaba en esa época, don Juan Manuel Cobo, los Ministros titulares don José Alejo Valenzuela, don José Miguel Bascuñán, don José Gaspar de la Carrera, el Fiscal Sr. Bernardino Antonio Villa y el Secretario don José Manuel Bezanilla.

Le correspondió a nuestra Corte de Apelaciones, el honor de ser la segunda de este tipo que entrara en funciones en el país, precediéndola sólo la Corte de Apelaciones de Santiago. Su creación había sido dispuesta por una ley que aprobó el Parlamento el 26 de noviembre de 1845, ley dentro de la cual se comprendió además la creación de la Corte de Apelaciones de Concepción. Cuatro años después, el 7 de julio de 1849, por Decreto Supremo del Gobierno de don Manuel Bulnes se dispuso la instalación de ambas Cortes para el $1^{\circ}$ de septiembre de aquél año, sin embargo en el caso de la nuestra se adelantó su funcionamiento para el día 26 de agosto, con el propósito de hacerlo coincidir con el aniversario de los 300 años de la segunda fundación de la ciudad hecha por don Francisco de Aguirre y que había tenido lugar el 26 de agosto de 1549.

Sin dejar de admitir la posibilidad de error a que está expuesta toda empresa humana, tenemos el firme convencimiento que nuestra Corte a través de los años, ha cumplido mayoritariamente con el papel a ella encomendado de dar fiel aplicación a la Constitución y a las leyes de la República y dentro de ese marco jurídico poner en ejercicio la constante y perpetua voluntad de dar a cada cual lo suyo, esto es poner en práctica la administración de la justicia. 
Aprovecho la ocasión de encontrarnos en una Escuela de Derecho, crisol dentro del cual se forman nuevos profesionales del foro para exhortar a los alumnos a que perseveren con ahínco en el estudio de lo jurídico con el fin de que puedan defender más eficazmente los derechos de sus representados, misión que respecto de los litigantes encarga a los abogados el Art. 520 del Código Orgánico de Tribunales. Los sorprende hoy en día una época de numerosos e importantes cambios en la legislación, lo cual demandará de Uds. y de nosotros también, el aprendizaje de nuevos procedimientos y destrezas, como ocurrirá con la puesta en marcha en un futuro no muy lejano, del nuevo procedimiento penal que sustituirá casi íntegramente nuestro actual Código del ramo, transformación jurídica de proporciones en que nos ha cabido la distinción y responsabilidad de iniciar su puesta en práctica en calidad de región piloto, lo que es un desafío para todos nosotros y que a fin de llevarlo a feliz término habremos de dar lo mejor de nuestros esfuerzos con el fin de que nuestra experiencia sirva de modelo a las restantes regiones del país.

Pero, sin perjuicio de lo anterior, esto es del constante ejercicio del intelecto en el estudio del derecho - estudio que como verán después en la práctica no han hecho otra cosa que iniciarlo y que deberán continuar durante toda su vida profesional, ya sea rememorando antiguos conocimientos ya opacados en la memoria por el transcurso del tiempo, o bien incorporando a su haber jurídico las nuevas reformas de tan continua ocurrencia - llamaré su atención sobre un aspecto al que lamentablemente muchas veces no se le da la importancia que le corresponde y que es aquél de ejercer la profesión de abogado, o la magistratura por aquellos que fueren llamados a ella, inspirados en aquellos principios que están grabados en la conciencia de los seres humanos, y que son los mismos que inspiran a la Universidad y a la Escuela de Derecho que los cobija, entre los cuales destaca la honradez y la consideración hacia los demás, principios cuya práctica importará que no defraudarán las expectativas y confianza que hayan depositado en Uds. sus clientes y representados y que mantendrán una relación a un nivel digno con colegas, magistrados y funcionarios judiciales. Creo que la cortesía y la buena educación son parte de la consideración al prójimo, lo que a su vez debe estimarse como parte integrante de la virtud de la generosidad, las que son una conveniente práctica en el ejercicio profesional y en la vida. Ojalá que esta generosidad, que va más allá del compartir los bienes y que en este caso es referente también a dar algo, pero algo más intangible, como es el buen trato, reine en vosotros y conlleve como contrapartida el destierro del egoísmo que nos impulsa a veces a la tentación de creernos los dueños de la verdad y a despreciar en virtud de ello las opiniones de los otros. No se olviden que sus armas serán aquellas del conocimiento, experiencia y habilidad jurídicas y no las de la descalificación despectiva al colega o al magistrado, muestra de 'envanecimiento y egoísmo, ésta última, que amén de convertir en un desagrado el ejercicio de la profesión, no hablará muy bien de la índole espiritual del litigante. No se olviden además que es propio de esta carrera la confrontación, pero no olviden tampoco que quienes controvierten son las partes y que Uds. solamente son quienes los representan. Destierren de Uds. en lo posible el vicio de la ira, que con tanta frecuencia trata de invadirnos, la que al decir de los proverbios de Salomón, el rey de Israel que eligió la sabiduría, "ciega" y "trae contienda". Que no sea su actuar solamente producto de una conveniencia 


\section{Discursos}

que alguien plasmó con aquella frase que dice "que los juicios pasan y los jueces quedan", sino que esperamos sea el efecto de acendrados principios cristianos que los inspiren y que los hagan llegar al final del camino que todos habremos de recorrer, con una conciencia limpia y habiendo cumplido con lo que Dios manda.

Reitero mis agradecimientos en nombre de mis colegas y en el mío propio por la señalada consideración que se ha tenido a nuestro respecto y por la acogida fraterna que se nos brinda en el sesquicentenario del tribunal de que formamos parte y que hoy en día me cabe el honor de presidir. 